\title{
Influence of Aleyrodidae Fly Population on Cotton Crop Diseases under Different Environmental Conditions
}

\author{
Mazhar Abbas', M. Afzal Qamar², S. Ehtisham-ul-Haque ${ }^{3}$, \\ M. Kamran Rafique ${ }^{3}$, Aneela Anwar ${ }^{4}$, Nasir Masood ${ }^{5}$, M. Asif Tahir ${ }^{6}$, \\ Numrah Nisar ${ }^{7}$, Munawar Iqbal ${ }^{8 *}$ \\ ${ }^{1}$ Institute of Molecular Biology and Biotechnology, The University of Lahore, Lahore, Pakistan \\ ${ }^{2}$ Govt. Postgraduate College, Samanabad, Faisalabad \\ ${ }^{3}$ Department of Pathobiology, College of Veterinary and Animal Sciences, Jhang, Pakistan \\ ${ }^{4}$ Department of Basic Sciences and Humanity, University of Engineering, KSK G. T Road Lahore, Lahore \\ ${ }^{5}$ COMSATS Institute of Information Technology, Vehari 61100, Pakistan \\ ${ }^{6}$ Department of Chemistry, University of Agriculture, Faisalabad 38040, Pakistan \\ ${ }^{7}$ Department of Environmental Sciences, Lahore College for Women University Lahore, Lahore, Pakistan \\ ${ }^{8}$ Department of Chemistry, The University of Lahore, Lahore, Pakistan
}

Received: 11 March 2016

Accepted: 22 June 2016

\begin{abstract}
Aleyrodidae fly is a vector carrier of various diseases in crops, plants, and vegetables. The present investigation evaluated the Aleyrodidae fly population for its relationship with cotton disease under different environmental conditions. Faisalabad, Chiniot, Sargodha, Jhang, Toba Tek Singh (T. T. Singh), and Burewala from Punjab, Pakistan were selected for this study. The Aleyrodidae fly population was found to be significantly different in selected regions, and endosymbionts of Hamiltonella, Rickettsia, Fritschea, Cardinium, Arsenophonus, and Wolbachia were recorded in promotions to the Aleyrodidae fly population. The Hamiltonella co-infection percentages in Faisalabad, Chiniot, Sargodha, Jhang, T. T. Singh, and Burewala were recorded as $51,28,75,8,23$, and 25 , respectively, whereas relative abundance percentages of Hamiltonella endosymbiont were recorded as 52, 35, 65, 5, 20, and 21 in Faisalabad, Chiniot, Sargodha, Jhang, T. T. Singh, and Burewala, respectively. A similar trend was observed for Rickettsia, Fritschea, Cardinium, Arsenophonus, and Wolbachia co-infection and relative abundances. Results revealed that the Aleyrodidae fly is a carrier of different endosymbionts, which were significantly different under different environmental conditions.
\end{abstract}

Keywords: Aleyrodidae fly, co-infection, relative abundance, cotton crop, environmental conditions

\footnotetext{
*e-mail: chemuaf@gmail.com
} 


\section{Introduction}

The Aleyrodidae fly (whitefly) belongs to the Aleyrodidae family, which damages various crops, ornamentals plants, and fruits (including legumes, citrus, avocado, banana, garlic, cassava, coconut, cauliflower, eggplant, mustard, guava, tobacco, mango, onion, pepper, cotton, cabbage, squash, capsicum, radish, soybean, peach, and tomato). The cotton crop is one of the important cash crops of Pakistan and is a soft target of Aleyrodidae [12]. Aleyrodidae reproduction is very fast and up to 1,200 eggs per square inch has been reported on cotton crops. Under favorable environmental conditions (temperature, humidity, weather), the Aleyrodidae population grows rapidly and resultantly damages the crop. It is an insect vector of cotton leaf curl virus disease in Pakistan. It transmit the virus efficiently during phloem feeding and is carried as a primary and vegetative facultative relationship with endosymbionts of bacterial origin [3-25], i.e., during feeding from leaf phloem, Aleyrodidae, other than primary endosymbionts, also carry different insects as a secondary endosymbiont, namely Fritschea [26], Hamiltonella [27], Arsenophonus [28], Cardinium [29], Wolbachia [30], and Rickettsia [31]. The reported secondary endosymbionts are not specified for their specific location, but they exist with host insects [32]. The relationships between Aleyrodidae and secondary endosymbionts are not essential for its survival, but play an important role in different metabolic processes during development, reproduction, and viral transmission.

Previously, some researchers studied the Aleyrodidae population, i.e., Gottlieb et al. [33] identified Rickettsia and [34] recorded the endosymbionts with the Aleyrodidae population [34]. It is reported that Rickettsia improved fitness of Aleyrodidae by increasing its fertility, enhancing the population [35], and increasing tolarance against unfavorable conditions [36]. Along with its beneficial potential for the host, due to over-populating, this symbiont increases susceptibility to insecticides and is harmful for the host [37]. Wolbachia belongs to Proteobacteria, which infects insects and is transmitted through eggs. It produces abnormality in the cytoplasmic system during the early growth phase of development [38-39]. Hamiltonella is fully dependent on the host for survival [40], and its host endosymbiotic relation plays a major role in transmission of different plant viruses [41]. Arsenophonus belongs to Proteobacteria phylum and is in arthropods, including psyllids, aphids, louse flies, and flies [42]. In cotton crops, Arsenophonus carry secondary endosymbiotics with Aleyrodidae in transmission of viruses by producing molecular protein, which interferes with the outer protein coat that is an easy target for the transmission virus in cotton crops [43]. Cardinium changes the cytoplasmic incompatibilities [44] and produces functional biomolecules like proteins, which interfere with the normal cell [45]. Fritschea belongs to the genus Candidatus [46] and is present in the gut of the Aleyrodidae fly [47].
Our investigation studied Aleyrodidae's relationships with various endosymbiots like Hamiltonella, Rickettsia, Fritschea, Cardinium, Arsenophonus, and Wolbachia under various environmental conditions in Punjab, Pakistan. Our principle objectives were to appraise the relative abundance of and co-infection of the endosymbionts under investigation.

\section{Material and Methods}

Aleyrodidae samples were collected from Faisalabad, Chiniot, Sargodha, Jhang, T. T. Singh, and Burewala, and studied for their DNA genome following the method reported by [48]. Amplifiable DNA was checked using sodium channel gene-specific primers as internal control and the presence of endosymbionts was evaluated using $16 \mathrm{~S}$ primers. Endosymbiont-specific primers were compared with [49]. The sample from each site was collected in triplicate and data thus obtained was reported as mean $\pm \mathrm{SD}$.

\section{Results and Discussion}

Aleyrodidae fly influence on endosymbiont and coinfection from different areas in cotton crop was studied and DNA was checked for endosymbiont relationship. The results obtained are given in Figs 1-2. We observed that coinfection of endosymbionts in Aleyrodidae fly collected from cotton fields of the Punjab districts of Faisalabad, Chiniot, Sargodha, Jhang, T. T. Singh, and Burewala were significant. We found that Fritschea was present in all collected samples, but the highest percentage was observed in samples collected from Sargodha (67\%), followed by Burewala $(51 \%)$, Faisalabad $(50 \%)$, Jhang $(48 \%)$, Chiniot (38\%), and T. T Singh (19\%). The Hamiltonella endosymbiont was recorded at maximum in Sargodha and minimum in Jhang, and the overall trend was as: Sargodha $(65 \%)>$ Faisalabad $(52 \%)>$ Chiniot $(35 \%)>$ Burewala $(21)>$ T. T. Singh (20\%), and Jhang (4\%). Rickettsia was found only in Sargodha and Jhang, which was 25\% and $23 \%$, respectively, whereas other districts revealed a very low percentage of Rickettsia. Cardinium was detected in all sampling areas and the percentages of Cardinium in Faisalabad, Chiniot, Sargodha, Jhang, T. T. Singh, and Burewala were found to be $53 \%, 51 \%, 8 \%, 27 \%, 10 \%$, and $11 \%$, respectively. Arsenophonus endosymbiont was also detected in the sampling area, but the variation within the area was significant and 55\%, 95\%, 9\%, 6\%, 26\%, and $11 \%$ were observed in Faisalabad, Chiniot, Sargodha, Jhang, T. T. Singh, and Burewala, respectively. Wolbachia was also recorded in all sampling areas and, in comparison to other endosymbionts, the Wolbachia percentage was very low. Wolbachia was recorded in the range of $8-26 \%$, with the highest in Sargodha and the lowest in Chiniot and Jhang. Co-infection of endosymbionts were detected in all samples. In Faisalabad, Hamiltonella, Arsenophonus, Fritschea, and Cardinium were present, While in 
Chiniot Arsenophonus and Cardinium were maximum. In Sargodha, Hamiltonella and Fritschea were recorded maximum, whereas Rickettsia and Cardinium were documented in Jhang. The co-infection trend in Toba Tek Singh was documented in Hamiltonella and Fritschea, but Rickettsia and Cardinium were present in Burewala.

In Pakistan, the cotton crop is susceptible to different diseases [50] and there are various factors responsible for this variety. The carrier vector and endosymbionts in whiteflies are two factors that harm the cotton leaf by folding and cause diseases in combination with viruses. In other countries, this trend of disease in cotton was
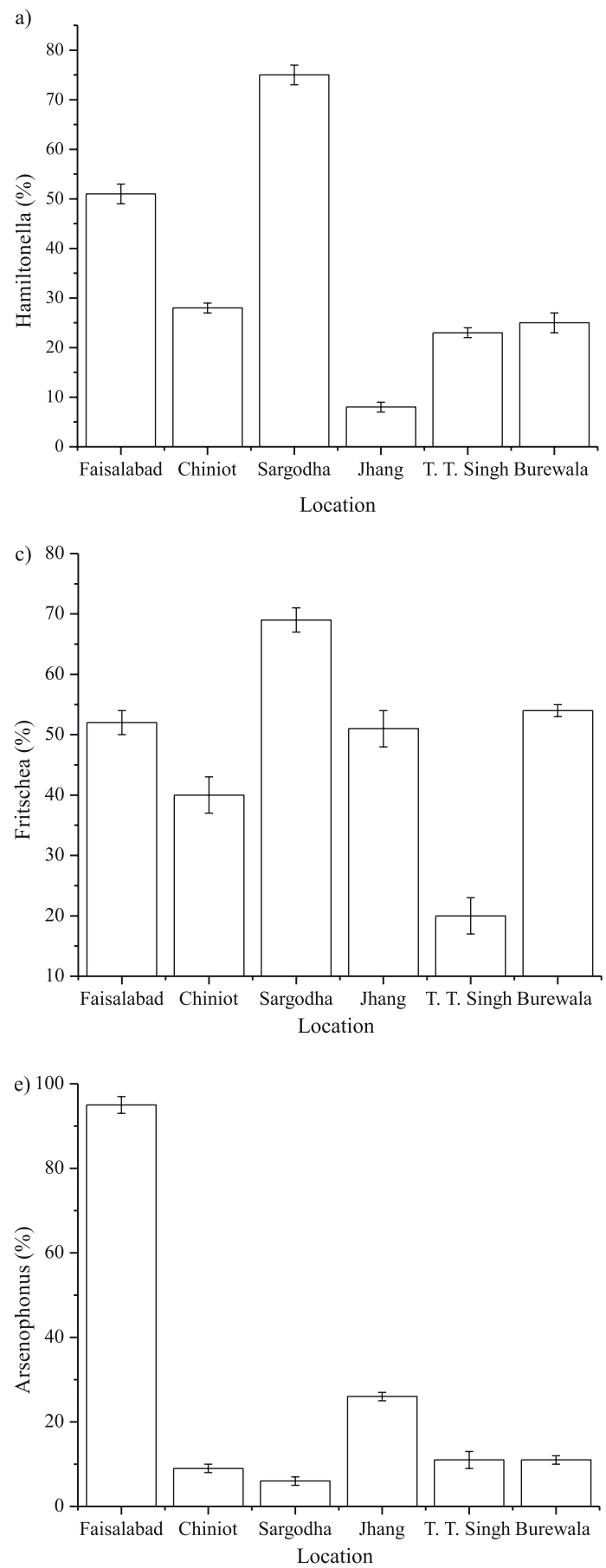

also observed and in China five types of secondary endosymbionts have been detected in cotton crops with significance in different regions. The authors correlated this disease with whiteflies in the studied area and a similar trend was observed in the present investigation [36]. A similar study has also been reported in Brazil, where the endosymbiont population was found to be significantly different in different areas [51].

The present study focused on various endosymbiont population evaluations in different areas of Punjab, and the overall trend was found to be in line with previous studies showing that endosymbionts may vary depending
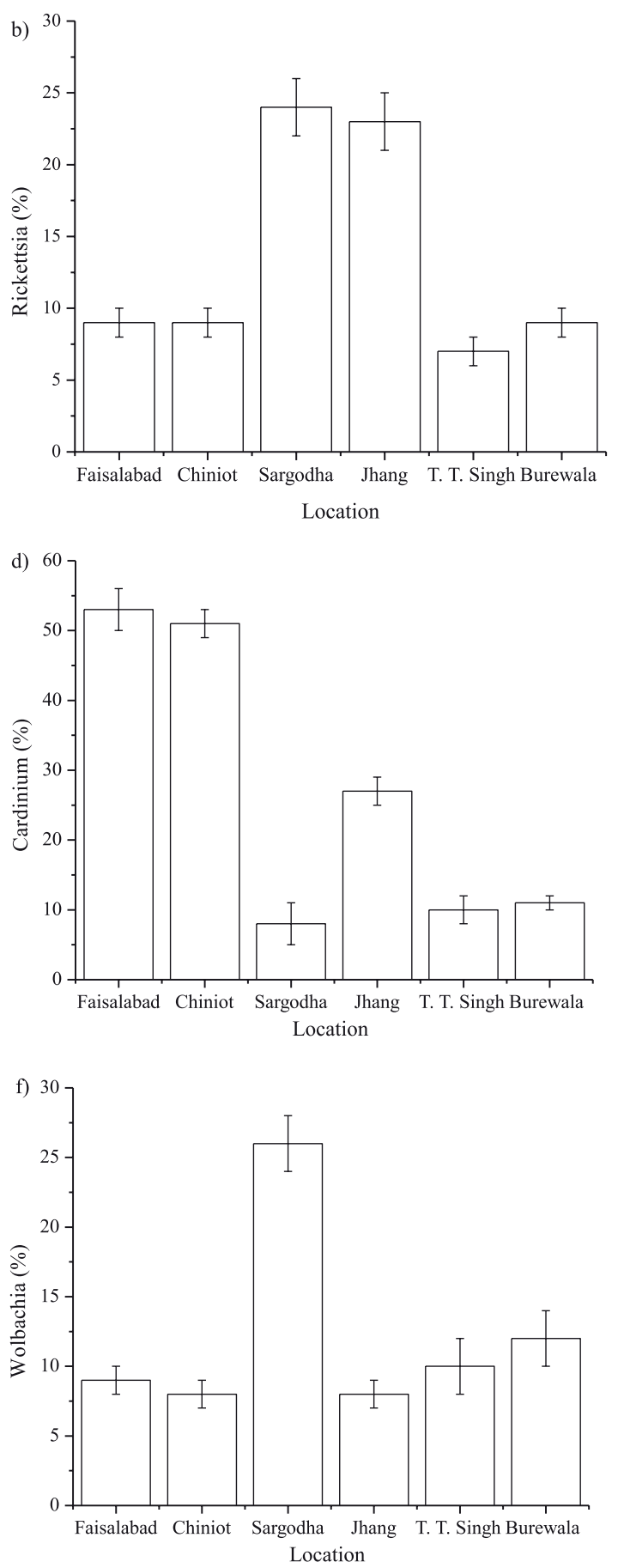

Fig. 1. Co-infection of endosymbionts (\%) in different studied areas. 
upon the population of whiteflies. The trend in coinfection was also found to be similar to endosymbiont percentages, which revealed that co-infection also has a relationship with the endosymbiont population. Therefore, co-infection factor also depends upon the whitefly population. From results of the present study, we observed that whiteflies play a significant role in diseases in cotton crops, but whiteflies work with a combination of different factors, such as environmental conditions of a particular area and bio-vectors.
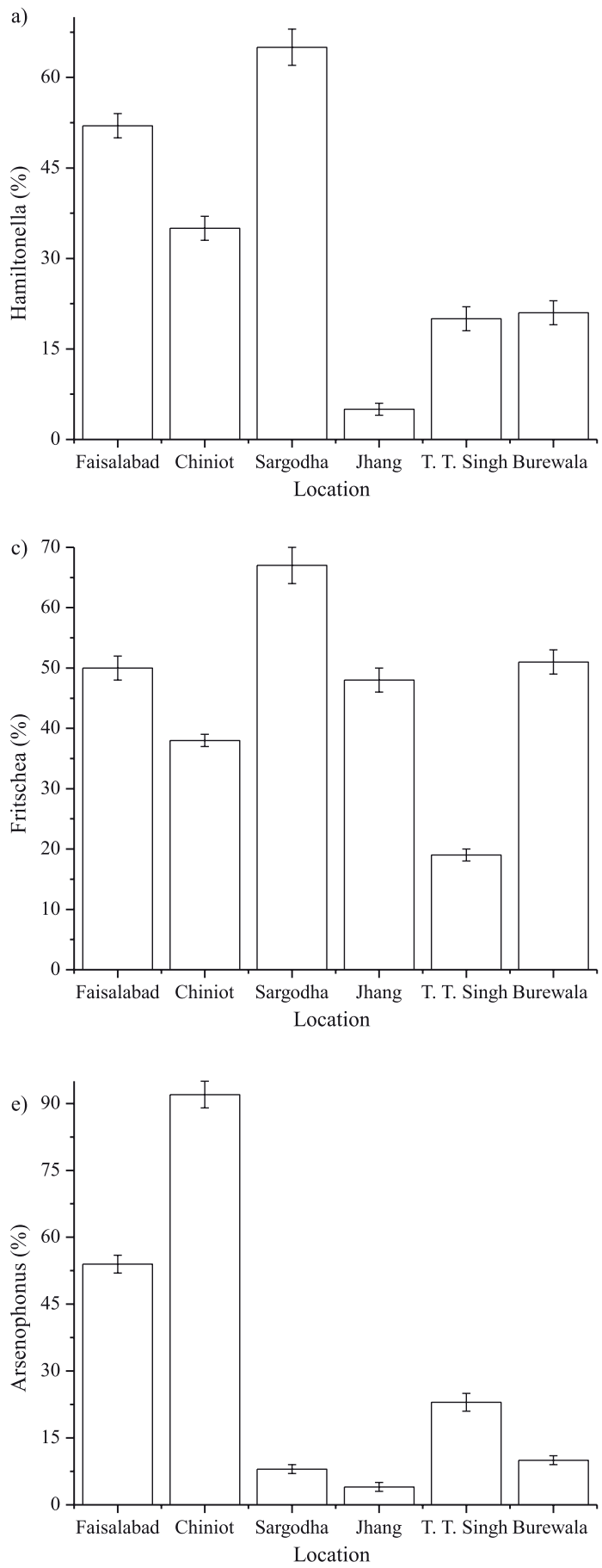

\section{Conclusions}

The Aleyrodidae fly relationship with various endosybionts in cotton crop was evaluated from Faisalabad, Chiniot, Sargodha, Jhang, T. T. Singh, and Burewala districts in Punjab, Pakistan. The Aleyrodidae fly population was found to be significantly different in selected regions and endosymbionts, i.e., Hamiltonella, Rickettsia, Fritschea, Cardinium, Arsenophonus, and Wolbachia. The Hamiltonella co-infection percentage in Faisalabad, Chiniot, Sargodha, Jhang, T. T. Singh, and Burewala were recorded to be in the range of $8-51 \%$,
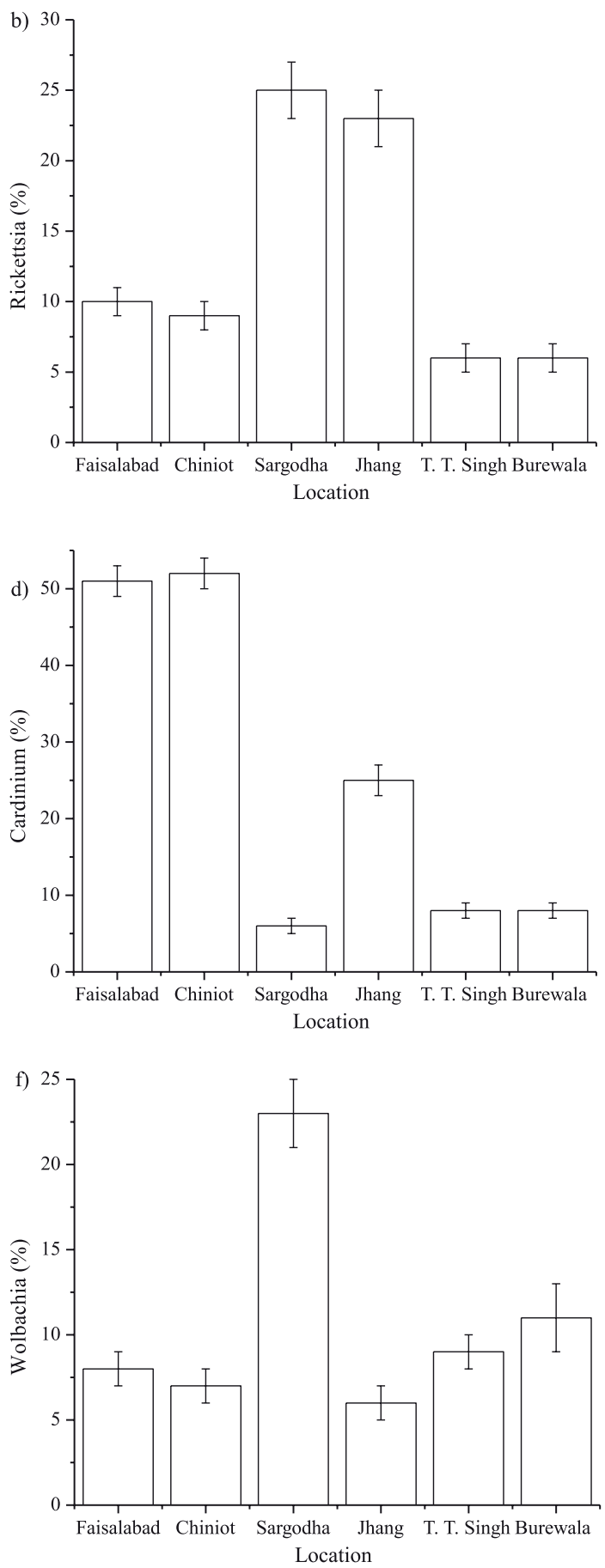

Fig. 2. Relative abundance of endosymbionts (\%) in different studied areas. 
whereas relative abundances were recorded in the range of 5-65\%. Overall, the trends of Hamiltonella, Rickettsia, Fritschea, Cardinium, Arsenophonus and Wolbachia co-infection and relative abundances were found to be variable and significant in all studied areas. Results revealed that the Aleyrodidae fly is a carrier of different endosymbionts, which were significantly different under variable environmental conditions.

\section{References}

1. ATTIQUE M., RAFIQ M., GHAFFAR A., AHMAD Z., MOHYUDDIN A. Hosts of Bemisia tabaci (Genn.) (Homoptera: Aleyrodidae) in cotton areas of Punjab, Pakistan. Crop Protect. 22, 715, 2003.

2. SYED T., ABRO G., KHUHRO R., DHAUROO M. Relative resistance of cotton varieties against sucking pests. Pakistan J. Biol. Sci. 6, 1232, 2003.

3. CHEN X., WANG R., CAO Q., ZHANG H., GE X., LIU J. The Relationship between the Distribution of Invasive Plant Alternanthera philoxeroides and Soil Properties is ScaleDependent. Pol. J. Environ. Stud. 24, 1931, 2015.

4. GE W., JIAO Y., ZOU J., JIANG W., LIU D. Ultrastructural and photosynthetic response of Populus 107 leaves to cadmium stress. Pol. J. Environ. Stud. 24, 519, 2015.

5. SEVIK H., CETIN M. Effects of water stress on seed germination for select landscape plants. Pol. J. Environ. Stud. 24, 689, 2015.

6. GRZESIK M., ROMANOWSKA-DUDA Z. Ability of Cyanobacteria and green algae to improve metabolic activity and development of willow plants. Pol. J. Environ. Stud. 24, $1003,2015$.

7. MOLAZEM D., BASHIRZADEH A. Impact of Salinity Stress on Proline Reaction, Peroxide Activity, and Antioxidant Enzymes in Maize (Zea mays L.). Pol. J. Environ. Stud. 24, 597, 2015.

8. NOWAK K., TRZEWIK A., TUŁACZ D., ORLIKOWSKA T., ORLIKOWSKI L. Characterization of Polish Phytophthora lacustris isolates Obtained from water environments. Pol. J. Environ. Stud. 24, 619, 2015.

9. SZCZEPAŃSKA N., OWCZAREK K., KUDŁAK B., POKRYWKA A., MAZERSKA Z., GAŁUSZKA A., NAMIEŚNIK J. Analysis and bioanalysis: an effective tool for data collection of environmental conditions and processes. Pol. J. Environ. Stud. 25, 45, 2016.

10. NAMIEŚNIK J. Modern trends in monitoring and analysis of environmental pollutants. Pol. J. Environ. Stud. 10, 127, 2001.

11. WINID B. Environmental threats of natural water contamination with polybrominated diphenyl ethers (PBDEs). Pol. J. Environ. Stud. 24, 47, 2015.

12. CHEN G., HE, H., GAO H., LI H., ZHANG Z. Differential responses of two rice varieties to perchlorate stress. Pol. J. Environ. Stud. 24, 67, 2015.

13. LEJMAN A., OGÓREK R., SOBKOWICZ P. Effects of Mechanical Weed Control in Barley-Pea Mixture on Colonization of Barley Grain by Fungi, Part 1. Pol. J. Environ. Stud. 24, 141, 2015.

14. LI Y., CHEN Z., XU S., ZHANG L., HOU W.,YU N. Effect of combined pollution of $\mathrm{Cd}$ and $\mathrm{B}[\mathrm{a}] \mathrm{P}$ on photosynthesis and chlorophyll fluorescence characteristics of wheat. Pol. J. Environ. Stud. 24, 157, 2015.

15. LIU J., ZHOU Z., SUN S., NING X., ZHAO S., XIE W.,
WANG Y., ZHENG L., HUANG R., LI B. Concentrations of heavy metals in six municipal sludges from Guangzhou and their potential ecological risk assessment for agricultural land use. Pol. J. Environ. Stud. 24, 165, 2015.

16. MATYSIK M., ABSALON D., RUMAN M. Surface water quality in relation to land cover in agricultural catchments (Liswarta River basin case study). Pol. J. Environ. Stud. 24, 175, 2015.

17. MAZUR Z., MAZUR T. Influence of long-term fertilization on phosphorus, potassium, magnesium, and sulfur content in soil. Pol. J. Environ. Stud. 24, 185, 2015.

18. SHEN N., ZHOU J., ZOU W. Energy efficiency measures and convergence in China, taking into account the effects of environmental and random factors. Pol. J. Environ. Stud. 24, 257, 2015.

19. SHI H., YANG Z., HAN F., SHI T., LI D. Assessing landscape ecological risk for a world natural heritage site: a case study of Bayanbulak in China. Pol. J. Environ. Stud. 24, 269, 2015.

20. SWĘDRZYŃSKA D., GRZEŚ S. Microbiological parameters of soil under sugar beet as a response to the longterm application of different tillage systems. Pol. J. Environ. Stud. 24, 285, 2015.

21. VULEVIĆ T., DRAGOVIĆ N., KOSTADINOV S., SIMIĆ S.B., MILOVANOVIĆ I. Prioritization of soil erosion vulnerable areas using multi-criteria analysis methods. Pol. J. Environ. Stud. 24, 317, 2015.

22. TAO L., GUO M., REN J. Effects of cadmium on seed germination, coleoptile growth, and root elongation of six pulses. Pol. J. Environ. Stud. 24, 295, 2015.

23. BELLOTTI A.C., ARIAS B. Host plant resistance to whiteflies with emphasis on cassava as a case study. Crop Protect. 20 (9), 813, 2001.

24. BROWN J., CAMPODONICO O., NELSON M. A. whitefly-transmitted geminivirus from peppers with tigré disease. Plant Disease. 73, 7, 1989.

25. BROWN J.K., CZOSNEK H. Whitefly transmission of plant viruses. Adv. Bot. Res. 36, 65, 2002.

26. ZCHORI-FEIN E., BROWN J. Diversity of prokaryotes associated with Bemisia tabaci (Gennadius)(Hemiptera: Aleyrodidae). Ann. Entomol. Soc. Am. 95 (6), 711, 2002.

27. GOTTLIEB Y., GHANIM M., CHIEL E., GERLING D., PORTNOY V., STEINBERG S., TZURI G., HOROWITZ A. R., BELAUSOVE., MOZES-DAUBEN., KONTSEDALOV S., GERSHON M., GAL S., KATZIR N., ZCHORI-FEIN E. Identification and localization of a Rickettsia sp. in Bemisia tabaci (Homoptera: Aleyrodidae). Appl. Environ. Microbiol. 72 (5), 3646, 2006

28. WEINERT L.A. The incidence of bacterial endosymbionts in terrestrial arthropods. Proc. Royal Soc. London B: Biol. Sci. 282, 249, 2015.

29. FUJIWARA A. Genetic groups and endosymbiotic microbiota of the Bemisia tabaci species complex in Japanese agricultural sites. Journal of Applied Entomology, 139, 55, 2015.

30. GNANKINE O. Distribution of Bemisia tabaci (Homoptera: Aleyrodidae) biotypes and their associated symbiotic bacteria on host plants in West Africa. Insect Conserv. Diversit. 6, 411, 2013.

31. SKALJAC M., ZANIC K., BAN S. G., KONTSEDALOV S., GHANIM M. Co-infection and localization of secondary symbionts in two whitefly species. BMC Microbiol. 10(1), 142, 2010.

32. ZUG R., HAMMERSTEIN P. Bad guys turned nice? A critical assessment of Wolbachia mutualisms in arthropod hosts. Biol. Rev. 90, 89, 2015. 
33. GOTTLIEB Y., ZCHORI-FEIN E., MOZES-DAUBE N., KONTSEDALOV S., SKALJAC M., BRUMIN M., SOBOL I., CZOSNEK H., VAVRE F., FLEURY F., GHANIM M. The transmission efficiency of Tomato yellow leaf curl virus by the whitefly Bemisia tabaci is correlated with the presence of a specific symbiotic bacterium species. J. Virol. JVI.00423, 10, 2010.

34. MORAN N.A., TELANG, A. Bacteriocyte-associated symbionts of insects. Biosci. 295, 304, 1998.

35. WERREN J. H. Biology of wolbachia. Ann. Rev. Entomol. 42 (1), 587, 1997.

36. GOTTLIEB Y., GHANIM M., CHIEL E., GERLING D., PORTNOY V., STEINBERG S., TZURI G., HOROWITZ A. R., BELAUSOVE., MOZES-DAUBE N., KONTSEDALOV S., GERSHON M., GAL S., KATZIR N., ZCHORI-FEIN E. Identification and localization of a Rickettsia sp. in Bemisia tabaci (Homoptera: Aleyrodidae). Appl. Environ. Microbiol. 72 (5), 3646, 2006.

37. HIMLER A.G., ADACHI-HAGIMORI T., BERGEN J.E., KOZUCH A., KELLY S.E., TABASHNIK B.E., CHIEL E., DUCKWORTH V.E., DENNEHY T.J., ZCHORI-FEIN E., HUNTER M.S. Rapid spread of a bacterial symbiont in an invasive whitefly is driven by fitness benefits and female bias. Sci. 332 (6026), 254, 2011.

38. BRUMIN M., KONTSEDALOV S., GHANIM M. Rickettsia influences thermotolerance in the whitefly Bemisia tabaci B biotype. Insect Sci. 18 (1), 57, 2011.

39. KONTSEDALOV S., ZCHORI-FEIN E., CHIEL, E., GOTTLIEB Y., INBAR M.,GHANIM M. The presence of Rickettsia is associated with increased susceptibility of Bemisia tabaci (Homoptera: Aleyrodidae) to insecticides. Pest Manage. Sci. 64 (8), 789, 2008.

40. GHANIM M., KONTSEDALOV S. Susceptibility to insecticides in the Q biotype of Bemisia tabaci is correlated with bacterial symbiont densities. Pest Manage. Sci. 65 (9), 939, 2009.

41. KLIOT A. Implication of the bacterial endosymbiont Rickettsia spp. in interactions of the whitefly Bemisia tabaci with Tomato yellow leaf curl virus. J. Virol. 88, 5652, 2014.
42. CHIEL E., GOTTLIEB Y., INBAR M., ZCHORI-FEIN E., GHANIM M. Distribution of secondary symbionts in Israeli populations of Bemisia tabaci. Bull. Entomol. Res. 97, 407, 2007.

43. CALLAINI G., DALLAI R., RIPARBELLI M.G. Wolbachiainduced delay of paternal chromatin condensation does not prevent maternal chromosomes from entering anaphase in incompatible crosses of Drosophila simulans. J. Cell Sci. 110 (2), 271, 1997.

44. LAVEN H., ASLAMKHAN M. Control of Culex pipiens pipiens and C. P. fatigans with integrated genetical systems. Pak. J. Sci. 22, 303, 1970.

45. O'NEILL S.L., HOFFMAN A., WERREN J.H. Influential passengers: inherited microorganisms and arthropod reproduction. Oxford University Press, 1997.

46. RAGAB A.I. Genetic variability of the whitefly Bemisia tabaci and its secondary endosymbionts in the Arabian Peninsula, 2013.

47. BING X.L., RUAN Y.M., RAO Q., WANG X.W., LIU S. S. Diversity of secondary endosymbionts among different putative species of the whitefly Bemisia tabaci. Insect. Sci. 20 (2), 194, 2013.

48. DEGNAN P.H., YU Y., SISNEROS N., WING R.A., MORAN N.A. Hamiltonella defensa, genome evolution of protective bacterial endosymbiont from pathogenic ancestors. Proc. Natl. Acad. Sci. 106 (22), 9063, 2009.

49. SKALJAC M., ZANIC K., BAN S.G., KONTSEDALOV S., GHANIM M. Co-infection and localization of secondary symbionts in two whitefly species, BMC Microbiol. 10, 1, 2010.

50. CHIEL E., GOTTLIEB Y., INBAR M., ZCHORI-FEIN E., GHANIM M. Distribution of secondary symbionts in Israeli populations of Bemisia tabaci. Bull. Entomol. Res. 97, 407, 2007.

51. MARUBAYASHI J.M., KLIOT A., YUKI V.A., REZENDE J.A.M., KRAUSE-SAKATE R., PAVAN M.A. GHANIM M. Diversity and Localization of Bacterial Endosymbionts from Whitefly Species Collected in Brazil. PLoS ONE 9 (9), 108363, 2014. 